\title{
Reformas del Estado Democrático: Subsidiariedad y Visión del Gobierno Limitado
}

Reforming the Democratice State: Sibsidiarity and a Vision of Limited Gobernment

Prof. Dr. Augusto Zimmermann Zimmermann, PhD

Professor of Law - Murdoch University

Artículo Original (Miscelánea)

RFJ, No. 1, 2017, pp. 241-253, ISSN 2588-0837

RESUMEN: Aunque sus raíces se remontan a la filosofía política de Aristóteles, la interpretación teológica de Tomás de Aquino de la filosofía política de Aristóteles resultó ser el catalizador para el nacimiento del principio de subsidiariedad que con el tiempo, se convertiría en un aspecto clave del pensamiento social católico romano. A pesar de las similitudes con la enseñanza calvinista y su conocido concepto de "soberanía de la esfera" como principio del pensamiento social católico, la subsidiariedad se introdujo por primera vez en la encíclica Rerum Novarum (1891) y se enunció en encíclicas posteriores como Quadragesimo Anno (1931) y Mater et Magistra (1961).

PALABRAS CLAVE: democrático, gobierno, derechos y política, pensamiento social, principios.

ABSTRACT: While its roots can be traced as far back as Aristotle's political philosophy, Thomas Aquinas's theological interpretation of Aristotle's political philosophy proved to be the catalyst for the birth of the principle of subsidiarity, which would in time become a key aspect of Roman Catholic social thought. Despite similarities with Calvinist teaching and its well-known concept of "sphere sovereignty" as a principle of Catholic social thought, subsidiarity was first introduced in the encyclical Rerum Novarum (1891) and was enunciated in subsequent encyclicals such as Quadragesimo Anno (1931) and Mater et Magistra (1961).

KEY WORDS: Democratic, government, rights and political, social tought, principals. 


\section{INTRODUCTION}

While its roots can be traced as far back as Aristotle's political philosophy, Thomas Aquinas's theological interpretation of Aristotle's political philosophy proved to be the catalyst for the birth of the principle of subsidiarity that would in time become a key aspect of Roman Catholic social thought. ${ }^{91}$ Despite similarities with Calvinist teaching and its well-known concept of "sphere sovereignty," ${ }^{22}$ as a principle of Catholic social thought, subsidiarity was first introduced in the encyclical Rerum Novarum (1891) and was enunciated in subsequent encyclicals such as Quadragesimo Anno (1931) and Mater

91 Subsidiarity in the writings of Aristotle and Aquinas - Nicholas Aroney pg 1 and 12. '[T]he critical point for the emergence of the principle lay in Thomas Aquinas's theological interpretation of Aristotle's political philosophy...And yet, Aquinas's social thought and the Catholic principle of subsidiarity retain the unmistakable marks of Aristotle's political philosophy.'

92 In 1880 Abraham Kuyper developed the concept of "sphere sovereignty." Kuyper-a Dutch theologian, academic, and politician-believed that God was present in 'every sphere of life' and that, consequently, each sphere-for example, 'family life, economic life, churchly life, sports'-must be sovereign. According to Kuyper, the individual may operate in several spheres at once; for example, as 'a member of a church, a citizen of the state, and a participant in any number of social spheres. In all these aspects of life, the basic convictions of the Christian faith would direct his or her activities.' See Kent A. Van Til, 'Subsidiarity and Sphere-Sovereignty: A Match Made In...?' (2008) 69 Theological Studies 610, 619-626. According to Lael Daniel Weinberger, sphere sovereignty and subsidiarity are fundamentally self-complimentary concepts, each recognising a distinct aspect of social relationships within a healthy, functioning society. As he points out, 'sphere sovereignty, like subsidiarity, offers a vision of institutional and social pluralism. Sphere sovereignty originates from a different theological tradition than subsidiarity and there are doubtless areas where sphere sovereignty's reformed theological tradition leads to a different emphasis and distinct theological formulations from that found in the Catholic tradition. Notwithstanding the differences, sphere sovereignty and subsidiarity complement each other by fleshing out two important sides to social pluralism. Subsidiarity focuses on the relationships between larger and smaller, "greater" and "lesser," organisations. Sphere sovereignty focuses on the relationships between organisations with distinct purposes, regardless of their size or position on a chain of command. Both the horizontal and the vertical aspects are important components of any well-functioning, diverse society.' See Lael Daniel Weinberger, 'The Relationship Between Sphere Sovereignty and Subsidiarity,' in Evans, M. and Zimmermann, A. (2014). Global Perspectives on Subsidiarity (Dordrecht: Springer) 115. 
et Magistra (1961). In Quadragesimo Anno Pope Pius XI outlined the principle as follows:

Just as it is gravely wrong to withdraw from the individual and commit to the community at large what private enterprise and industry can accomplish, so, too, it is an injustice, a grave evil, and a disturbance of right order for a larger and greater organisation to arrogate to itself functions which can be performed efficiently by smaller and lower bodies. This is a fundamental principle of social philosophy, unshaken and unchangeable. Of its very nature the true aim of all social activity should be to help individual members of the social body, but never to destroy or absorb them. ${ }^{93}$

Having roots in the Latin word subsidium, subsidiarity simply means to "help" or "assistance." In keeping with the spirit of the Latin understanding, subsidiarity mandates that an obligation be imposed on higher governing orders to help or assist lower orders to flourish. Understood in this sense, the principle of subsidiarity opposes centralising, bureaucratising forms of government and mass welfare assistance, which deprive citizens of their responsibility toward themselves, their families, and their societies. Instead, subsidiarity protects individual liberty and promotes individual responsibility, recognising that the best way to achieve the common good is through the spontaneous actions of, and interactions between, free and responsible individuals. Subsidiarity, therefore, is a bulwark of limited government, advocating that 'intermediate social entities can properly perform the functions that fall to them without being required to hand them over unjustly to other social entities of a higher level, by which they would end up being absorbed and substituted, in the end seeing themselves denied their dignity and essential place.' ${ }^{94}$

93 Pius XI, Quadragesimo Anno: Reconstructing the Social Order and Perfecting it Conformably to the Precepts of the Gospel in Commemoration of the Fortieth Anniversary of the Encyclical 'Rerum Novarum' (Australian Catholic Truth Society, 1931) 25. For a discussion of this quotation, see Robert K. Vischer, 'Subsidiarity as a Principle of Governance: Beyond Devolution' (2001) 35 Indiana Law Review 103, 107-108, cited in Peter Widulski, 'Bakke, Grutter, and the Principle of Subsidiarity' (2005) 32 Hastings Constitutional Law Quarterly 847, 847.

94 Pontifical Council for Justice and Peace, Pontifical Council for Justice and Peace. London: Burns \& Oates, 2005, 94. 


\section{SUBSIDIARITY AND DEMOCRATIC PLURALISM}

In Centesimus Annus (1991) Pope John Paul II stated that human nature is not completely fulfilled in the State, but is realised in various intermediary groups, beginning with the family, including economic, social, political and cultural groups that stem from human nature itself and have their own autonomy.' ${ }^{95}$ Accordingly, citizens must be empowered and encouraged to participate in local decisionmaking, which enhances democracy because it shifts the balance of power towards individuals, away from the central government, preventing political power from concentrating in a few hands. By dividing political power, individual rights are protected through, as James Madison described it, a 'double security.' 'In the compound republic of America,' Madison stated, the power surrendered by the people is first divided between two distinct governments, and then the portion allotted to each [is] subdivided among distinct and separate departments. Hence a double security arises to the rights of the people. The different governments will control each other, at the same time that each will be controlled by itself. ${ }^{96}$

When the will of the majority is expressed in the legal order, conformity to this legal order, - to the will of the majority, -is the primary aim of democracy. But what if the norms, the rules expressed in the legal order, central to the will of the majority and applicable to the entire body politic, contradict the majority will of smaller subsections of the body politic? In order to diminish the possible contradictions, Hans Kelsen contended that democracy is better achieved when political power is fragmented. Kelsen argued that 'it may be necessary, under certain circumstances, that certain norms of the legal order be valid only for certain partial territories and be created only by majority of votes of the individuals living in these territories.' ${ }^{97}$

This plurality of political orders consists of different spheres of governance, each of them possessing its proper limits of responsibility and jurisdiction. When applied in the context of a federal system, Australian law professor Anne Twomey says, 'subsidiarity provides that functions should, where practical, be vested in the lowest level of government to ensure that their exercise is as close to the people

95 John Paul II, Centesimus Annus, [13].

96 Madison (1961) 323.

97 Kelsen (1945) 313. 
as possible and reflects community preferences and local conditions.' ${ }_{98}$ Accordingly, subsidiarity postulates that one should not leave to the central government what the local government itself can do in an either better or similar way, since only that which cannot be done otherwise by the lower levels of government it must be left in the hands of the central government.

\section{MORAL COSTS OF STATE PATERNALISM}

But it is equally relevant to observe that the first foundational form of every democratic government is personal self-government, based on the autonomy of free and responsible individuals. Unfortunately, however, people today are naturally inclined to look on government aid as a right, regarding themselves as perfectly entitled to every public assistance. This prevents them from considering their selfworth and making attempts to preserve their self-respect. Rather, the philosophy of state paternalism unmistakably discourages any such virtues, 'giving money first and then fostering dependency, forgetting entirely about self-respect, and then discouraging a path to independence.' ${ }^{99}$ After describing the moral costs of state paternalism, the Reverend Robert Sirico concluded that

[t]he welfare state pursues its tasks in terms of a moral code increasingly alien from traditional Christian tenets. For example, the very concept of a welfare "entitlement" runs contrary to the scriptural understanding of aiding the poor: helping others is a moral duty that springs from spiritual commitment and is not essentially exercised through coercion or government mandates. The modern, central state has proven itself incapable of distinguishing between the deserving and the underserving poor, and between aid that fosters independence and moral development from that which reinforces a dependency mindset and moral nihilism.

Arguably, welfare assistance cannot eliminate the more pressing moral and spiritual needs that lie at the heart of every dysfunctional

98 Twomey, A. (2008). 'Reforming Australia’s Federal System'. 36 Federal Law Review $57,59$.

99 Sirico, R. (2014). 'Subsidiarity and the Reform of the Welfare of the Nation State', in Michelle Evans and Augusto Zimmermann, Global Perspectives on Subsidiarity (Dordrecht: Springer) 123. 
behaviour. Sometimes what the recipient of such assistance actually needs is a strong message of work and sobriety. As such, although government aid can benefit some individuals, it is effectively a band aid for a broken bone:

Government aid can actually make things worse. By handing out welfare checks impersonally to all who qualify, without addressing the underlying behavioural problems, the government in essence 'rewards' antisocial and dysfunctional patterns. And any behavior the government rewards will generally tend to increase. As one perceptive nineteenth century critic noted, government assistance is a 'might solvent to sunder the ties of kinship, to quench the affections of family, to suppress in the poor themselves the instinct of selfreliance and self-respect - to convert them into paupers. ${ }^{100}$

The increase of criminality in England is a prime example. The idea that poverty or social conditions are sufficient causes of crime cannot be supported empirically. On the contrary, political commentator Peter Hitchens explains that, in his native England.

The evidence shows that he highest levels of crime in memory have occurred at a time of unheard-of...social welfare...This destroys the idea that increased welfare leads to a reduction in crime. On the contrary, it raises the possibility that well-meaning state intervention to improve the lot of the poor can actually lead to increased crime... It is the decay of moral values and self-restraint...that have led to the misery of the modern poor. ${ }^{101}$

Regarding the impact of government aid on the common good, perhaps nobody has better explained how such assistance may eventually undermine the spirit of self-restraint and responsibility than Wilhelm von Humboldt (1767-1835), the German liberal philosopher and founder of the Humboldt University of Berlin. He explained that

[t]he evil results of a too excessive solicitude on the part of the State, are still more strikingly shown in the suppression of all active energy, and the necessary deterioration of the moral character. ... The man who is often led, easily becomes disposed willingly to sacrifice what

100 Pearcey, N.R. (2004). Total Truth: Liberating Christianity from its Cultural Captivity (Wheaton/Ill: Crossway,) 61.

101 Hitchens (2003). 23. 
remains of his capacity for spontaneous action. He fancies himself released from an anxiety which he sees transferred to other hands, and seems to himself to do enough when he looks to their leadership and follows it. Thus, his notions of merit and guilt become unsettled. ... He now conceives himself not only completely free from any duty which the State has not expressly imposed upon him, but exonerated at the same time from every personal effort to improve his own condition; and, even fears such an effort, as if it were likely to open out new opportunities, of which the State might take advantage...Further, as each individual abandons himself to the solicitous aid of the State, so, and still more, he abandons to it the fate of his fellow-citizens. This weakens sympathy and renders mutual assistance inactive; or, at least, the reciprocal interchange of services and benefits...where the feeling is most acute that such assistance is the only thing to rely upon; and experience teaches us that oppressed classes of the community which are...overlooked by the government, are always bound together by the closest ties. But whether the citizen becomes indifferent to his fellows, so will the husband be to his wife, and the father of a family towards the members of his household. ${ }^{102}$

Arguably, in no other field are the moral costs of statism more visible than in the field of family policy. Although the family serves as a primary means of acculturation and transmission of values from generation to generation, family ties in today's societies are so weak that fewer people think they ought to help their family members. As a result, people in distress no longer expect to obtain much help this way. ${ }^{103}$ Rather than addressing these problems, public policy seems to have further destabilised the family with disastrous consequences. ${ }^{104}$ For example, the last few decades have seen the dramatic proliferation of laws allowing the unilateral dissolution of the marriage contract. By making divorce easily available and purely personal, the state has transformed marriage into a legal absurdity that denies the doctrine of responsibility and holds no inducements to personal misconduct. These inducements provide a strong temptation for selfish and unethical behaviour. Whenever and wherever the family breaks down, of course,

102 von Humboldt, W. (1792). The Limits of State Action. Chapter 3 available at: http://ebooks.adelaide.edu.au/h/humboldt/wilhelm_von/sphere/chater3.html

103 Acton, H.B. (1993). The Morals of Markets and Related Essays (edited by D Gordon and J Shearmur, Liberty Fund) 81-2.

104 Sirico, above n 18, 116. 
the state must step in as a substitute for the dysfunctional family. Hence the gradual increase of the state's jurisdiction over the family.

Additionally, one should also consider how welfare assistance, which is a pseudonym for government-mandated redistribution of private wealth, stymies the ability of individuals to provide charitable assistance. When these assets are taken from the individual and their social groups, it leaves very little for them to donate to private charity. According to the English political philosopher John Gray, the regime of high taxation inseparable from government welfare diminishes the sphere of free services in which individuals engage in spontaneous relations, effectively 'corroding the culture of civility that sustains liberal civilization.' ${ }^{105}$ The inevitable consequence of this decrease in individual charitable activities is that the state acquires greater financial power to invest in the charitable activities that the state deems it worthy to support:

If, because of the confiscation of higher incomes, there are important social and cultural activities that can no longer be sustained privatelysuch as provision for high culture and the arts-then once again the state assumes responsibility for such activities through a program of subsidy. Inevitably, the state comes to exercise an ever-increasing degree of control over them. The consequence of redistributionist policy, accordingly, is the curtailment of private initiative in many spheres of social life, the destruction of the man of independent means, and in the weakening of civil society.

So who are the principal beneficiaries of the welfare state? And what impact does this amassing of power in the state have on the common good? In Deus Caritas Est (2005), Pope Benedict XVI correctly noted that '[t]he State which would provide everything, absorbing everything into itself, would ultimately become a mere bureaucracy incapable of guaranteeing the very thing which the suffering personevery person- needs: namely, loving personal concern.' ${ }^{106}$ Despite the seemingly good intentions of state paternalism, all that is actually achieved is the creatation of a huge and expensive bureaucracy that is sustained by a permanent underclass of chronically poor people and their families. To a great extent, the reality of redistributionist policies is that, primarily, they result in 'a redistribution of power from

105 Gray (1990) xiii.

106 Deus Caritas Est (2005) [28(b)]. 
the individual to the State. ${ }^{{ }^{107}}$ Ultimately, this increase of centralized power creates a new, elite ruling class; a class of state-appointed officials. As noted by Tom G. Palmer,

[t]he poor suffer the worst, because a trickle of benefits may seem like a boom to them, when their very poverty is both perpetuated by the welfare state and deepened by the hidden transfers from the powerless to the powerful caused by protectionism, licensing, and other restriction on labour market freedoms, and all the other privileges and special deals the powerful, the educated, the articulated, and the empowered create for themselves at the expense of the weak, the uneducated, the voiceless, and the disempowered. ${ }^{108}$

\section{SUBSIDIARITY AND REFORM OF THE DEMOCRATIC STATE}

In Centesimus Annus (1991) John Paul II stated that human nature 'is not completely fulfilled in the State, but is realised in various intermediary groups, beginning with the family, including economic, social, political and cultural groups which stem from human nature itself and have their own autonomy.' ${ }^{109}$ The encyclical goes on to explain that the 'malfunctions and defects' of the welfare state are the direct result of an 'inadequate understanding of the tasks proper to the state.' Because of this, John Paul II concluded thatthe principle of subsidiarity must be respect[ed] [so that] a community of a higher order should not interfere in the internal life of a community of a lower order, depriving the latter of its functions, but rather should support it in case of need and help to coordinate its activity with the activities of the rest of society, always with a view to the common good. ... In fact, it would appear that needs are best understood and satisfied by people who are closest to them and who act as neighbours to those in need.

In this sense, subsidiarity must be understood as a principle of authentic help or assistance, which sets up the proper limits for governmental action. Since subsidiarity means help or assistance, the idea implies that higher orders can intervene in the affairs of lower orders only as auxiliary aid, and never as permanent substitutes. Above

\footnotetext{
107 de Jouvenel (1990) 76.

108 Palmer (2012b) 8.

109 John Paul II, Centesimus Annus, [13].
} 
all, subsidiarity is about providing moral and practical functions to the lower orders that are essential to a well-functioning democratic society. In Caritas et Veritate (2009) Benedict XVI emphasised this particular view of subsidiarity as an expression of inalienable human freedom. Subsidiarity is first and foremost a form of assistance to the human person via the autonomy of intermediate bodies. Such assistance is offered when individual or groups are unable to accomplish something on their own, and it is always designed to achieve their emancipation, because it fosters freedom and participation through assumption of responsibility. Subsidiarity respects personal dignity by recognizing in the person a subject who is always capable of giving something to others. By considering reciprocity as the heart of what it is to be a human being, subsidiarity is the most effective antidote against any form of all-encompassing welfare state. ${ }^{110}$

The principle of subsidiarity is therefore premised on empowering the individual with decision-making "carried out as close to the citizen as is viable' ${ }^{111}$ or, in simpler words, at a 'grassroots level.' ${ }^{112}$ That being so, it is taken as a basic assumption that 'intermediate social entities can properly perform the functions that fall to them without being required to hand them over unjustly to other social entities of a higher level, by which they would end up being absorbed and substituted, in the end seeing themselves denied their dignity and essential place.' ${ }^{113}$ A hierarchy of orders is thus established, consisting first of the individual as a self-governing entity endowed by God with inalienable rights to life, liberty and property. The individual is then followed by the family, the local community, the Church and, finally, the State.

In sum, subsidiarity emphasises a decentralising principle that stimulates a 'participatory structure of government,' ${ }^{114}$ buttressing

110 Caritas in Veritate (2009) [57].

111 Hunnings (ed), Encyclopaedia of European Law (Sweet \& Maxwell, 1998) s 12.0120A, cited in John Warwick Montgomery, 'Subsidiarity as a Jurisprudential and Canonical Theory' (2002) 148 Law and Justice The Christian Law Review 46, 48.

112 John Warwick Montgomery, 'Subsidiarity as a Jurisprudential and Canonical Theory' (2002) 148 Law and Justice: The Christian Law Review 46, 48.

113 Pontifical Council for Justice and Peace, Pontifical Council for Justice and Peace. London: Burns \& Oates, 2005, 94.

114 Zimmermann, A. (2014). Subsidiarity, Democracy and Individual Liberty in Brazil. in Evans, M. and Zimmermann, A. Global Perspectives on Subsidiarity (Dordrecht: Springer) 88. 
individual liberty and eschewing political elitism. In addition to promoting personal responsibility, subsidiarity-inspired decentralisation corresponds to a diminished redistributive welfare initiative which encourages active engagement in political, social, domestic and humanitarian affairs. And it is through these spontaneous interactions between free and responsible individuals that a more perfect vision of the common good and of good government may hope to be realised. One of the chief drafters of the American Declaration of Independence, Thomas Jefferson, expressed the same sentiment:

It is not by the consolidation or concentration of powers, but by their distribution that good government is effected...that division must be made that each might do for itself what concerns itself directly and what it can so much better do than a distant authority. Every state again is divided into counties, each to take care of what lies within its local bounds; each county again into townships or wards, to manage minuter details; and every ward into farms, to be governed each by its individual proprietor...It is by this partition of cares descending in graduation from general to particular that the mass of human affairs may be best managed for the good and prosperity of all. ${ }^{115}$

\section{CONCLUSION}

To conclude, subsidiarity recognises that there are certain aspects of human life that the state may not legitimately control. As a principle of government, subsidiarity rejects all forms of collectivism predicated on political centralisation and mass welfare assistance. After all, when governmental power increases, individual liberty must decrease, because an excess of governmental power inevitably diminishes personal choice and opportunity. Accordingly, "powerful" governments that make more and more decisions for the citizens eventually destroy all the incentives for spontaneous interaction and economic growth. If a nation embraces subsidiarity, however, it will be a basic principle of government that the power of the state must be decentralised and limited enough so that it does not actually take too much freedom from the individual.

115 Jefferson (1829) 66. 


\section{REFERENCES}

Acton, H.B. (1993). The Morals of Markets and Related Essays (edited by D Gordon and J Shearmur, Liberty

Hunnings (ed). Encyclopaedia of European Law (Sweet \& Maxwell, 1998) s 12.0120A, cited in John Warwick Montgomery, Subsidiarity as a Jurisprudential and Canonical Theory (2002) 148 Law and Justice The Christian Law Review 46, 48.

Pearcey, N. (2006). Total Truth: Liberating Christianity from its Cultural Captivity (Wheaton/Ill)

Pius XI, Quadragesimo Anno: Reconstructing the Social Order and Perfecting it Conformably to the Precepts of the Gospel in Commemoration of the Fortieth Anniversary of the Encyclical 'Rerum Novarum' (Australian Catholic Truth Society, 1931) 25.

Pontifical Council for Justice and Peace, Pontifical Council for Justice and Peace. London: Burns \& Oates, 2005, 94.

Pontifical Council for Justice and Peace, Pontifical Council for Justice and Peace. London: Burns \& Oates, 2005, 94.

Sirico, R. (2014). Subsidiarity and the Reform of the Welfare of the Nation State, in Michelle Evans and Augusto Zimmermann, Global Perspectives on Subsidiarity. (Dordrecht: Springer) 123.

Twomey, A. (2008). Reforming Australia's Federal System. 36 Federal Law Review. 57, 59.

Vischer, R. (2001). Subsidiarity as a Principle of Governance: Beyond Devolution. 35 Indiana Law Review 103, 107-108, cited in Peter Widulski, Bakke, Grutter, and the Principle of Subsidiarity (2005) 32 Hastings Constitutional Law Quarterly 847, 847.

Von Humboldt, W. (1972). The Limits of State Action. Chapter 3 available at http://ebooks.adelaide.edu.au/h/humboldt/wilhelm_von/sphere/chater3.html. 
Warwick Montgomery, J. (2002). Subsidiarity as a Jurisprudential and Canonical Theory. 148 Law and Justice: The Christian Law Review $46,48$.

Weinberger, L. W. (2014). The Relationship Between Sphere Sovereignty and Subsidiarity, in Michelle Evans and Augusto Zimmermann, Global Perspectives on Subsidiarity. (Dordrecht: Springer) 115.

Zimmermann, A. (2014). Subsidiarity, Democracy and Individual Liberty in Brazil, in Michelle Evans Augusto Zimmermann, Global Perspectives on Subsidiarity (Dordrecht: Springer) 88.

Recibido: 19/01/2017

Aprobado para publicación: 28/05/2017

Augusto Zimmermann (LLB, LLM, PhD): Es PhD por Monash University (Australia). Es ex Comisionado de Reforma Legislativa con la Comisión de Reforma Legislativa de Western Australia. El Dr. Zimmermann ha sido profesor titular y ex Decano Asociado (Investigación) y Director de Estudios de Posgrado en la Facultad de Derecho de la Universidad Murdoch y profesor en la U. De Rio de Janeiro. Es fundador y presidente de la Western Australian Legal Theory Association (WALTA), vicepresidente de la Sociedad Australiana de Filosofía Legal (ASLP) y editor en jefe del Western Australian Jurist law journal.

Correo electrónico: Augusto.Zimmermann@murdoch.edu.au 